\title{
Prevalence of the protozoan organisms in the Red Sea, Hurghada, Egypt
}

\author{
Mansour Galal \\ Faculty of Science, Menofyia Univ.
}

\begin{abstract}
This study was carried out in order to evaluate the distribution and availability of the various protozoan organisms in some stations at Hurghada on the Egyptian coast of the Red Sea beside their response to some of the physico-chemical parameters. Two main phyla were detected at these sampling stations; Ciliophora and Sarcomastigophora. The latter phylum is comprising two subphyla (Mastigophora and Sarcodina). Three various classes were detected in that phylum; Rhizopodea, Actinopodea and Phytomastigophorea. Three different classes of the ciliated protozoa were identified as well which are known as Kinetofragminophorea, Oligohymenophorea and Polyhymenophorea. The different classes of the protozoan organisms comprised too many orders (more than 24 orders) which were illustrated by more than 103 genera/ species. It was proved that certain physico-chemical parameters affect the prevalence of some of these protozoan organisms significantly from the statistical point of view. Simultaneously, time - series analysis proved the presence of cyclic changes in the physico-chemical parameters, protozoan abundance and their numerical densities which fluctuate with the time. This could be interpreted as a result of the presence of a chemostate situation.
\end{abstract}

Keywords: Prevalence, Protozoa, Red Sea, Hurghada, Egypt

\section{INTRODUCTION}

Protozoan organisms are important biotic components in the aquatic ecosystem, particularly ciliates, which mostly act as predators of bacteria, provide nutrition for organisms at higher trophic levels (Kneitel and Chase, 2004; Dopheide et al., 2009), increase mineralization and make nutrients more available to other organisms (Vickerman, 1992). They also play a crucial role in food chains as bio-monitors and/or indicators of water quality (Charubhun and Charubhun, 2000). Simultaneously, it was proved that protozoa stimulate the rates of carbon and nitrogen cycling (Fenchel, 1987 and Finlay et al., 2004). Data on protozoa are available in some plankton studies along the Egyptian Red Sea Coast (Dolan and Gallegos; 2001; Modgh and Castaldo, 2002 ; Abou Zaid and Hellal, 2012).

Various studies were carried out in the Red Sea for certain protozoan genera or species but from the taxonomical point of view. Very few investigations related to protozoan ecology were done mainly on the western coast of the northern part of the red sea including Aqaba and Suez gulves (Abu-zeid and Helal, 2012; El-Serehy et al., 2014 ; Zakaria, 2015).

In the Red Sea, evaporation is active and largely exceeds precipitation so that salinity is comparatively high. Surface salinity rapidly rises from less than $37 \mathrm{psu}$ at the southern entrance, to 40-41 psu in the northern part of the Red Sea and El-Aqaba Gulf, and to more than $41 \mathrm{psu}$ in the Suez Gulf. The average surface temperature fluctuates between $25^{\circ} \mathrm{C}$ and $32{ }^{\circ} \mathrm{C}$ in the south, $21.3^{\circ} \mathrm{C}$ and $27.9^{\circ} \mathrm{C}$ in the North of the Red Sea.

Halim (1969) carried out a preliminary study on both phyto- and zooplankton in the Red Sea and Gulf of Aqaba. Bergren and Boersma (1969) estimated the planktonic Foraminifera from the Red Sea, On the other hand, Weikert (1982) examined the influence of 


\section{Mansour Galal}

certain ecological parameters on the vertical distribution of zooplankton along the central part of the Red Sea.

An examination of plankton samples collected from the inshore and offshore waters in the vicinity of Hurghada area in the Egyptian Red Sea coast revealed the presence of about ninety two tintinnid ciliate species (Abou Zaid and Hellal, 2012). According to Zakaria (2015), Suez Canal caused a migration of the zooplanktonic organisms generally from Red Sea to the Mediterranean, and rarely in the opposite direction as Red Sea is generally saltier and more nutrient-poor than the Atlantic ocean, so the Red Sea species have advantages over Atlantic species in the salty and nutrient-poor eastern Mediterranean. Therefore, Red Sea species invaded the Mediterranean ecosystem and not vice versa; this phenomenon is known as the Lessepsian migration or erythrean invasion.

The main objective of the present study was to identify and to enumerate the various types of the protozoan organisms at sampling stations on the Egyptian coast of the Red Sea at Hurghada.

\section{MATERIALS AND METHODS}

The studying area includes six sampling stations around Hurghada Marine Research Institute on the Red Sea along six kilometers. Two types of samples (aquatic and sand sediment) were picked up during each sampling occasion between $8.0-9.0$ in the morning. Water samples_were collected using a water sampler of about one liter volume and then sedimentation was carried out via cold sedimentation technique at 5-7 ${ }^{0} \mathrm{C}$ according to Utermohl (1958). On the other hand, sand samples_were collected by pushing down a rectangular brass corer of $10 \mathrm{~cm}$ length and $1 \mathrm{~cm}^{2}$ cross section into the submerged sandy bottom to examine sand and its organisms. Sand of each corer was transported as quickly as we can to be washed with filtered sea water from a burette, through a double muslin tissue inside a glass funnel above a sedimentation unit (100 ml capacity) of two parts as could be seen in figure (1). Microscopical examination of protozoa was carried out using Carl- Zeiss Jena transmitted- light inverted microscope. Identification and classification were carried out via Corliss (1979) and Levin et al. (1980). It was found helpful to slow down the rapid movements of many of these protozoan organisms especially the ciliated ones by adding few drops of methyl cellulose solution (15 gm in $85 \mathrm{ml}$ water) to the preparation inside the basal part of the sedimentation chamber.

Physico-chemical parameters as water temperature, Dissolved oxygen, $\mathrm{pH}$ were measured by using a fixed thermometer inside water sampler, an oxygen meter and $\mathrm{p}^{\mathrm{H}}$ meter, while salinity, Ch-a, $\mathrm{PO}_{4} \& \mathrm{NO}_{3}$ were measured depending on APHA (2005).

The statistical tests including regression and time-series analyses were performed by using Minitab programe.

\section{RESULTS AND DISCUSSION}

The microscopical examination revealed that different types of the aquatic organisms were present in the collected samples at Hurghada coast. These organisms include rotifers, worms, crustacean, insect and polychaete larvae beside many types and numbers of different protozoan organisms. It was found that protozoa is the most abundant group. They are exhibited by two phyla; Ciliophora and Sarcomstigophora. The latter phylum includes two subphyla; Sacodina and Mastigophora in all the collected aquatic and sand samples. It was found that the former phylum illustrated about $65-74 \%$, while the latter one is represented by more or less $26-35 \%$ of the total protozoan organisms. Kingdom protista is represented, in the present investigation, by more than 103 protozoan species/genera belonging to different 24 orders of six classes; namely Rhizopodea, Actinopodea, Phytomastigophorea, 


\section{Prevalence of the protozoan organisms in the Red Sea, Hurghada, Egypt}

Kinetofragminophorea, Oligohymenophorea and Polyhymenophorea. The various numerical protozoan genera at the different sampling stations were 75 genus and more than 103 species.

It is worthy to mention that the highest numerical densities were obtained in class kinetofragminophorea (2087/L) followed by Oligohyminophorea (360/L), Polyhyminophorea (1172/L), Phytomastigophorea (584/L), Rhizopodea (86/L) and then Actinopodea (37/L) as could be seen in Table (1). In addition, the comparison between the prevalence of these protozoan organisms in both Mediterranean and Red seas proved that the protozoan numerical densities in the former sea is higher than those of the latter one. This situation could be interpreted as a result of the phenomenon of the Lessepsian migration or erythrean invasion (Zakaria, 2015).

The numerical densities of both aquatic and sediment ciliated protozoan organisms belonging to the previously mentioned groups indicated that the sediment samples having higher numerical densities than the aquatic ones by more or less one and half to double times apart from phytomastigophorea. Comparing the mean values of the numerical densities belonging to ciliated protozoa of the sand sediment in Hurghada against middle northern coast of Egypt proved that data of the latter sea exceeds those of the former one. This could be interpreted mainly as a result of the highly nutritive conditions of the Mediterranean Sea as compared with those of the Red one. Comparing the numerical values of the total ciliates, Kinetofragminophora, Oligohymenophora and Polyhymenophora, belonging to these two seas, it was proved that the data were in the favour of the former sea apart from those of Polyhymenophores. Variations in the present data could be attributed mostly to the predation influence of certain organisms as crustaceans, insect larvae and rotifers (Dolan et al., 1999; Pitta et al., 2001). This conclusion is supported by the present data of chlorophyll-a, the total nitrates and phosphates. It is necessary to keep in mind that slight variations in the physicochemical parameters were obtained at the various sampling stations in the present study.

Data of the physico-chemical parameters (Table 4) illustrated that the $\mathrm{p}^{\mathrm{H}}$ levels are slightly alkaline $(7.9-8.5)$, the salinity is $39-57 \%$, water temperature is $15.1-31.2{ }^{\circ} \mathrm{C}$, and dissolved oxygen is $6.2-8.3 \mathrm{mg} / \mathrm{L}$. The $\mathrm{p}^{\mathrm{H}}$ values affect most of the metabolic activities and consequently survival and growth of aquatic organisms (Ramanathan et al., 2005). The present data showed a parallel behaviour with temperature and dissolved oxygen as could be seen in Figure (2). Dissolved oxygen plays an important role in most of the biological functions of zooplankton. Simultaneously, both salinity and oxygen levels affect the solubility and availability of nutrients and hence productivity of aquatic ecosystems (Abdelmongy and El-Moselhy; 2015).

Simultaneously, the nutrient concentrations in that region of the Red sea are 3.7-4.9 $\mathrm{ug} / \mathrm{L}$ for $\mathrm{Ch}-\mathrm{a}$ and $0.051-0.065,0.017-0.033 \mathrm{mg} / \mathrm{L}$ for total nitrates and total phosphates respectively. Accordingly, it appears that our stations are more or less oligotrophic. Simultaneously, the numerical densities of the various taxa belonging to these protozoan organisms were examined against some of the physico-chemical factors using the Minitab package in order to detect the significance level of some of these factors on the distribution and the abundance of these unicellular organisms. It could be possible to prove that the total ciliated protozoa of the water samples are statistically significant with water temperature $(\mathrm{P}=0.026)$, dissolved oxygen $(\mathrm{P}=0.03)$ and total phosphates $(\mathrm{P}=0.03)$, while those of the sand samples are significant with the dissolved oxygen $(\mathrm{P}=0.05)$ and total phosphates only $(\mathrm{P}=0.02)$. On the other hand, it was proved that water phytomastigophorea represented a statistically significant relationships with water temperature, dissolved oxygen and chlorophyll-a values where their $\mathrm{P}$ values are $<0.001,<0.01$ and $<0.001$ respectively. The application of the time -series analysis to the data of the present study could be seen in Figure (2; A B C D E F and G). Time series analysis of the various protozoan organisms indicates the presence of cyclic changes in their abundance and the numerical densities which 


\section{Mansour Galal}

fluctuate with the time. Simultaneously, the examined physico-chemical parameters followed more or less a similar behavior which could be interpreted as a result of the presence of a chemostate situation.

According to the obtained data in several zooplankton studies along the Egyptian coasts (Abdel-Aziz; 2004; Abdel-Aziz and Aboul-Ezz, 2003; Anon, 2007), protozoa are considered as important biotic components in the aquatic ecosystem, particularly those acting as predators of bacteria and other micro-organisms beside some rotifers. They provide nutritive source for organisms at higher trophic levels (Kneitel and Chase 2004; Dopheide et al., 2009), increase mineralization to make nutrients more available to other organisms (Vickerman, 1992). They also play a crucial role as biomonitors and/or indicators of water quality (Charubhun and Charubhun, 2000).

Marine protozoa as radiolarians and foraminiferans have a biological significance in sediments only. Other marine sarcodines are difficult to be sampled efficiently due to their body fragility and their relatively low quantitative and qualitative abundance. Many of the phytoflagellates are difficult to be detected precisely using the microscope due to their very minute size. Simultaneously, most of the marine ciliated protozoan are widely distributed and dominate in both species numbers and types. In addition, protozoan organisms play a very important role in the food web (Lee and Choi, 2000) beside their high tolerance against extreme toxic environmental conditions such as exaggerated heavy metals and other pollutants (Forge et al., 1993).

Microbivorous protozoan organisms appear to stimulate the rates of carbon and nitrogen cycling (Fenchel, 1987 and Finlay et al., 2004). Ciliates feed mostly on bacteria and not on dissolved organic material, bacteria and flagellates compete for dissolved nutrients, while ciliates compete with other ciliates and rotifers. Due to the controlled human activities, the environmental parameters showed a quite aerobic conditions, moderate nutrient levels and efficient protozoan growth.
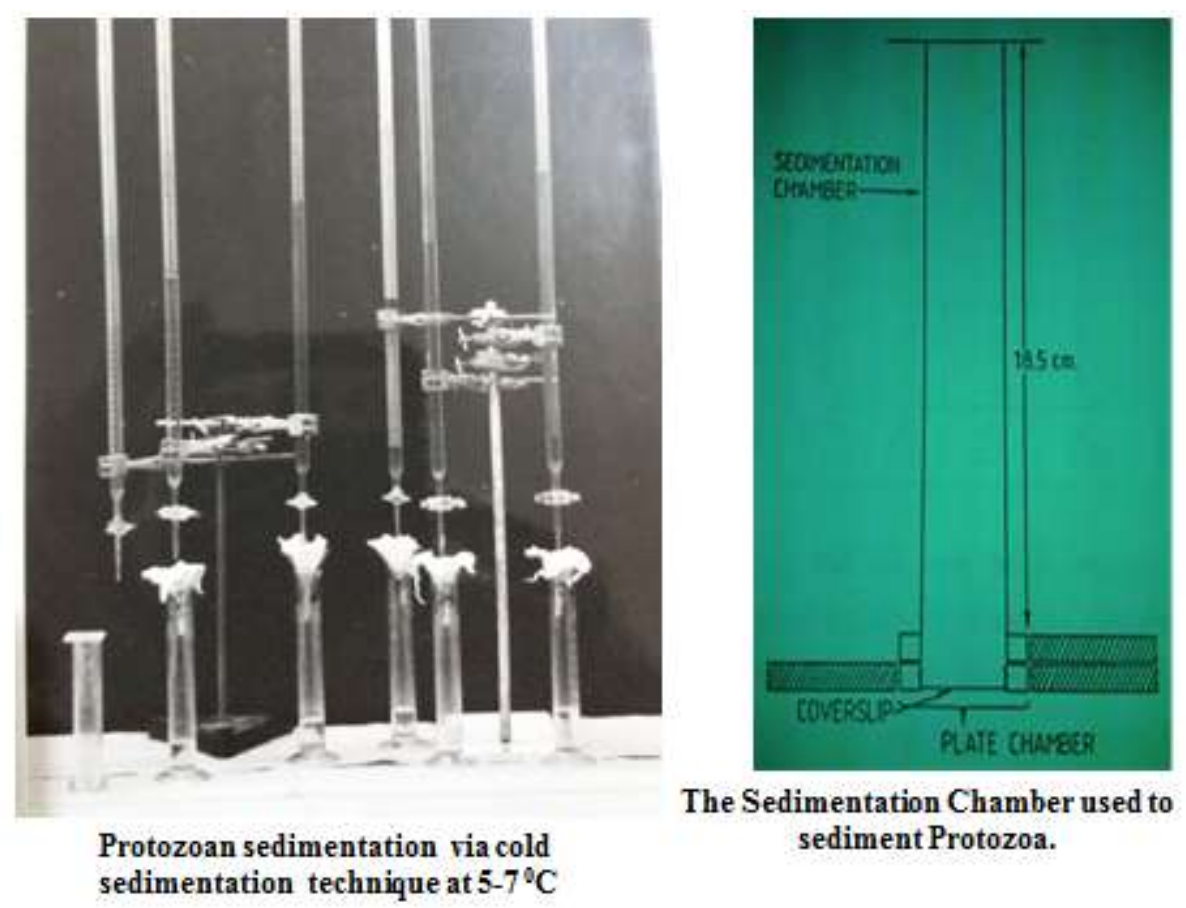

Fig. (1). The extraction and the sedimentation techniques of Protozoan organisms. 
Table (1). Numerical densities $\left(n^{0} / L\right)$ of different Protozoan organisms at the sampling stations in Hurghada, Egypt.

\begin{tabular}{|c|c|c|}
\hline Protozoan organisms & Protozoan organisms & Protozoan organisms \\
\hline Phylum: Sarcomastigophora & O: Haptorida & Oxytricha sp. $2 \mathrm{sp}$ \\
\hline Subphylum: Sarcodina & Lacrymaria $\mathrm{sp} \quad 1 \mathrm{sp}$. & Tachysoma sp. $1 \mathrm{sp}$ \\
\hline Class: Rhizopodea 66 & Spathidium sp. $\quad 1$ & Stylonychia sp. $1 \mathrm{sp}$ \\
\hline Amoeba sp. 2 sp. & Dileptus sp. $\quad 1$ & O:Heterotrichida \\
\hline Arcella sp. $1 \mathrm{sp}$. & Monodinium sp. $1 \mathrm{sp}$ & Stentor sp. $\quad 2 \mathrm{sp}$ \\
\hline Chaos sp. 1 & Didinium sp $\quad 1$ & Spirostomum sp. 1sp \\
\hline Difflugia sp. 1 & Mesodinium sp. $2 \mathrm{sp}$ & Blepharisma sp. $1 \mathrm{sp}$ \\
\hline Pelomyxa sp. 1 sp. & Subclass 2: Vestibuliferea & O: Oligotrichida \\
\hline Centropyxis sp. $1 \mathrm{sp}$. & O: Colpodida & Halteria sp. $\quad 1 \mathrm{sp}$ \\
\hline Saccamoeba sp. $1 \mathrm{sp}$ & Colpoda sp. $\quad 2 \mathrm{spp}$ & Strobilidium sp. 1 \\
\hline Vannella sp. $\quad 1$ & O: Trichostomatida & Strombidium sp 1 \\
\hline Class: Actinopodea 37 & Plagiopyla sp. $\quad 1 \mathrm{sp}$ & Tintinnidium sp. 1 \\
\hline Actinophrys sp. $\quad 1 \mathrm{sp}$. & Subclass 3: Suctoria & Codonella sp. $\quad 1$ \\
\hline Actinosphaerium sp. 1 & O: Suctorida & 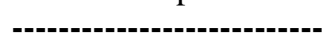 \\
\hline Globigerina sp $\quad 1$ & Acineta sp. & 75 genera/ 103 sp. \\
\hline Textularia sp. $\quad 1$ & Podophrya sp & \\
\hline Subphylum: Mstigophora & Tokophrya sp. & \\
\hline Class: Phytomastigophorea 584 & Class 2: Oligohymenophorea 360 & \\
\hline Euglena sp. $\quad 1 \mathrm{sp}$ & O: Hymenostomatida & \\
\hline Bodo sp. & Uronema sp. $\quad 2 \mathrm{spp}$ & \\
\hline Phacus sp. & Cinetochilum sp. $1 \mathrm{sp}$ & \\
\hline Monas sp. & Colpidium sp. $\quad 2 \mathrm{sp}$ & \\
\hline Peranema sp. & O: Scuticociliatida & \\
\hline Monosiga sp. & Cyclidium sp. $\quad 3 \mathrm{sp}$ & \\
\hline Chilomonas sp. & Pleuronema sp. $\quad 1$ & \\
\hline Cryptomons sp. & O: Peritrichida & \\
\hline Ceratium sp. $\quad 1$ & Carchesium sp. 1 & \\
\hline Chlamydomonas sp. 1 & Cothurnia sp. $\quad 1$ & \\
\hline Phylum: Ciliophora & Epistylis sp. & \\
\hline Class I: Kinetofragminophorea & Vaginicola sp. $\quad 1 \mathrm{sp}$ & \\
\hline 2087 & Opercularia sp. 1 & \\
\hline Subclass 1: Gymnostomatia & Ophrydium sp. 2 & \\
\hline O: Karyorelictida & Vorticella sp. $\quad 4 \mathrm{sp}$ & \\
\hline Loxodes sp. & O: Peniculinda & \\
\hline O:Prostomatida & Paramecium sp. $3 \mathrm{sp}$. & \\
\hline Holophrya sp. & Urocentrum sp. $2 \mathrm{sp}$ & \\
\hline Urotricha sp & Frontonia sp. $\quad 1$ sp & \\
\hline Coleps sp. & Class 3:Polyhymenophora 1172 & \\
\hline Prorodon sp. $\quad 1$ & Subclass: Spirotrichia & \\
\hline O: Pleurostomatida & O: Hypotrichida & \\
\hline Acineria sp. $\quad 1$ & Aspidiscia sp. $3 \mathrm{sp}$. & \\
\hline Amphileptus sp. & Urostyla sp. & \\
\hline Litonotus sp. & Euplotes sp. & \\
\hline Loxophyllum sp. & & \\
\hline Hemiophrys sp. & & \\
\hline Condylostoma sp & & \\
\hline
\end{tabular}




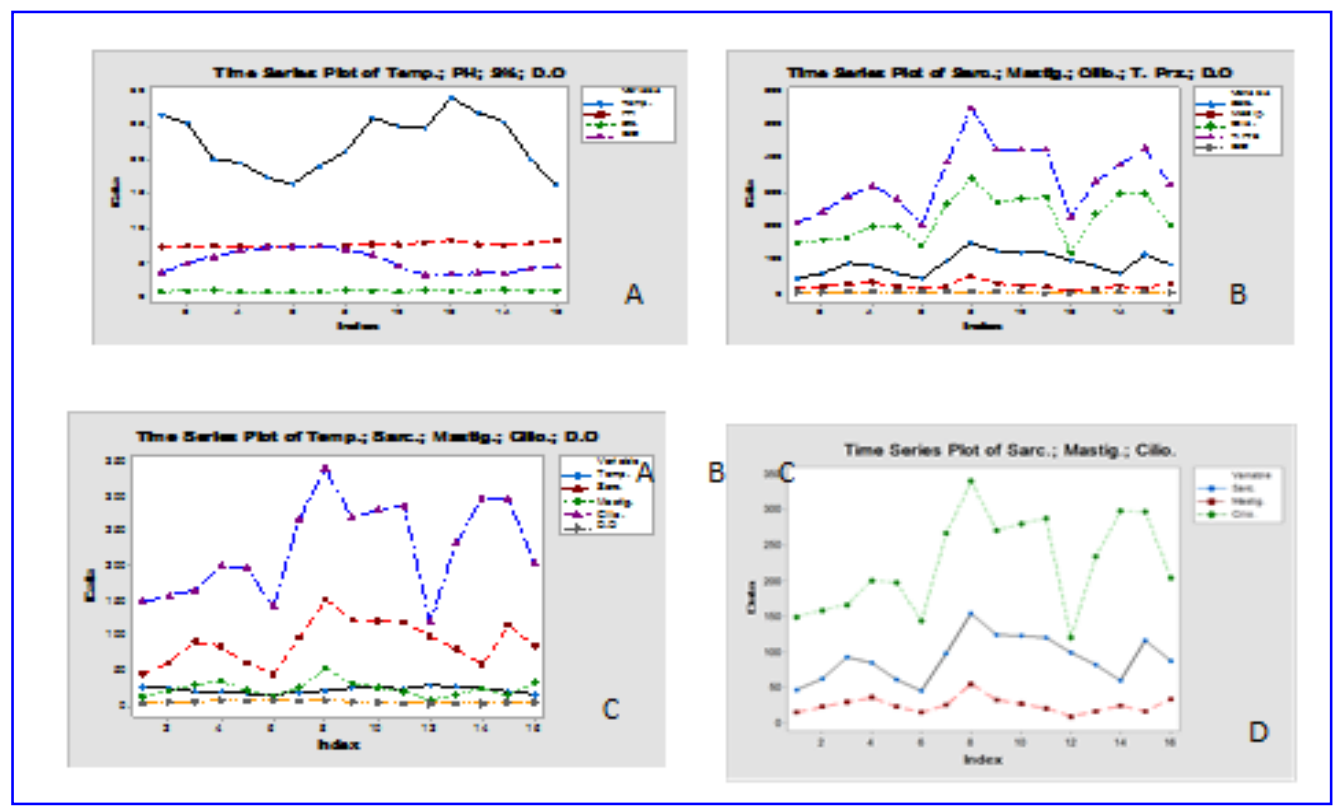

Fig. (2). Time Series Analysis of various protozoan classes and certain physico-chemical parameters at Hurghada, Egypt.

Table (2). Maximal numerical densities $\left(n^{0} / L\right)$ of the protozoan organism in different orders at the sampling localities in Hurghada, Red Sea, Egypt.

\begin{tabular}{|l|l|l|l|}
\hline Protozoan order & $\begin{array}{l}\text { Numerical } \\
\text { densities }\end{array}$ & Protozoan order & $\begin{array}{l}\text { Numerical } \\
\text { densities }\end{array}$ \\
\hline $\begin{array}{l}\text { Phylum: Sarcomastigophora } \\
\text { S.phylum: Sarcodia }\end{array}$ & $(121)$ & Phylum: Ciliophora & $(2087)$ \\
O : Euamoebida 53 & & Prostomatida & 109 \\
Arcellinida 32 & & Pleurostomatida & 275 \\
Pelobiontida 12 & & Haptorida & 241 \\
Actinophrida 11 & & Colpodida & 49 \\
Foraminiferida 13 & Trichostomatida & 37 \\
S.phylum: Mastigophora & $(584)$ & Suctorida & 61 \\
Euglenida 195 & & *Hymenostomatida & 360 \\
Bodonida 63 & & Peritrichida & 341 \\
Cryptomonadida 54 & & Peniculinida & 44 \\
Dinoflagellida 97 & & Hypotrichida & 397 \\
Chonoflagllida 80 & & Heterotrichida & 123 \\
Volvocalida 95 & & Oligotrichida & 50 \\
& & \\
\hline
\end{tabular}


Table (3). Comparable sand data in both Mediterranean and Red Seas.

\begin{tabular}{|l|l|l|}
\hline \multicolumn{1}{|c|}{ Sand Data } & Mediterranean Sea & Red Sea \\
\hline Tot. Nitrates mg/L & 0.060 & $\mathbf{0 . 0 5 1 - 0 . 0 6 5}$ \\
Tot. Posphates mg/L & 0.019 & $\mathbf{0 . 0 1 7 - 0 . 0 3 3}$ \\
Chlorophyll-a ug/L & 4.7 & $3.7-4.9$ \\
Kinetoframinophorea & 1176 & 965 \\
Oligohymenophorea & 457 & 792 \\
Polyhymenophorea & & 577 \\
\hline
\end{tabular}

Table (4). Values of certain physico-chemical parameters at the Herghada location of the present study.

\begin{tabular}{|l|l|}
\hline Prameters & Minimal \& Maximal values \\
\hline Water temp. ${ }^{\circ} \mathrm{C}$ & $15.1-31.2$ \\
Salinity (\%o) $_{\mathbf{P}^{\mathrm{H}}}$ & $39-57$ \\
Dis. Ox. $(\mathrm{mg} / \mathrm{L})^{\text {Total NO }}$ (mg/L) & $7.9-8.5$ \\
Total P O $_{3}(\mathrm{mg} / \mathrm{L})$ & $6.2-8.3$ \\
Ch-a $($ ug/L) & $\mathbf{0 . 0 5 - 0 . 0 6 5}$ \\
& $\mathbf{0 . 0 1 7 - 0 . 0 3 3}$ \\
\hline
\end{tabular}

\section{REFERENCES}

Abdel-Aziz, N.E. (2004). The changes of zooplankton community in a chronic eutrophic bay on Alexandria coast. Egypt. Bull. Fac. Sci. Alex. Univ., 43 (1-2): 203-220.

Abdel-Aziz, N.E. and Aboul-Ezz, S.M. (2003). Zooplankton community of the Egyptian Mediterranean Coast, Egypt. J. Aquat. Biol. Fish., 7 (4): 91-108.

Abdelmongy, A.S. and El-Moselhy, K.M. (2015). Seasonal variations of the chemical properties of seawater at the Northern Red Sea, Egypt. Open J. Ocean and Costal Sci., 2(1). DOI: 10.15764/OCS.2015.01001

Abou Zaid, M.M and Hellal, A.M.( 2012). Tintinnids (Protozoa: Ciliata) from the coast of Hurghada Red Sea, Egypt. Egyp. J. Aqua.Res., 38 (4): 249-268.

Anon, (2007). Final project report; distribution biological and rearing aspect of marine fish fries from Mediterranean Sea between Alexandria and Damietta. NIOS, Acad. Sci. Res., Alexandria.

APHA, American Public Health Association (2005). Standard methods for the examination of water and wastewater, American Public Health Association, $21^{\text {st }}$ ed, Academic Press, Washington D.C.

Bergren, W.A. and Boersma, A. (1969). Late Pleistocene and Holiocene planktonic foraminifera from the Red Sea. In: Hot Brines and Recent Heavy Metal Deposits in the Red Sea. Eds. E.T. Degens, and D.A. Ross, Berlin-Hedel beerg-New York. Pp. 282-291.

Charubhun, B. and Charubhun, N. ( 2000). Biodiversity of freshwater Protozoa in Thailand, Kasetsart J. (Nat. Sci.), 34: 486-494.

Corliss, J.O. (1979). The ciliated Protozoa. Characterization, classification and guide to the literature. Pergamon Press, Oxford.

Dolan, J.R.; Vidussi F. and Claustre, H. (1999). Planktonic ciliates in the Mediterranean Sea : longitudinal trends. Deep Sea Res., 1 (46): 2025-2039. 


\section{Mansour Galal}

Dolan, J.R and Gallegos, C.L. (2001). Estuarine diversity of tintinnids (planktonic ciliates. J. Plankton Res., 23: 1009-1027.

Dopheide, A.; Lear, G.; Stott, R. and Lewis, G. (2009). Relative diversity community structure of ciliates in stream biofilms according to molecular and microscopy methods. Appl. Environ. Microb., 75 (16): 5261-5272.

El-Serehy, H.A.; Khaled, A. Al-Rasheid and Hesham Shafik (2012). Microbial Loop Populations: Their Abundances and Trophodynamics in the Gulf of Aqaba, Red Sea. Turkish J. Fish. and Aquat. Sci., 12: 565-573.

Fenchel, T. (1987). Ecology of Protozoa: the biology of free living phagotrophic protists. Science Tech Publisher, Madison, and Springer-Verlag, Berlin.

Finlay, B.J.; Esteban, G.F. and Fenchel, T. (2004). Protist diversity is different? Protist 155:15-22.

Forge, T.A.; M.L. Berrow, J.F. Darbyshire and A.Warren. (1993). Protozoan bioassays of soil amended with sewage sludge and heavy metals, using the common soil ciliate Colpoda stenii. Biol. Fertil. Soils, 16: 282-286.

Halim, Y. (1969). Plankton of the Red Sea. Oceanogr. Mar.Biol., 7: 1-275.

Kneitel, J.M. and Chase, J.M. (2004). Disturbance, predator, and resource interactions alter container community composition, Ecology, 85 (8): 2088-2093.

Lee, W.J. and Choi, J.K. (2000). The role of heterotrophic protistis in the planktonic communities of Kyeonggi Bay, Korea. J.Kor.Soc.Oceanog., 35: 46-55.

Levine, N.D.; Corliss, J.O.; Cox, F.E.G.; Deroux, G.; Grain, J.; Hфnigberg, B.M.; Leedale, G.F.; Loeblich, A.R.; Lom, J.; Lynn, D.; Merinfeld, E.G.; Page, F.C.; Poljansky, G.; Sprague, V.; Vavra, J. and Wallace, F.G. (1980). A newly revised classification of the Protozoa. J. Protozool., 27: 37-58.

Modigh, M. and Castaldo, S. ( 2002). Variability and persistence in tintinnid assemblages at a Mediterranean coastal site. Aquat. Microbiol. Ecol., 28: 299-311

Pitta, P.; Giannakourou, A. and Christaki, U. (2001). Planktonic ciliates in the oligotrophic Mediterranean Sea: longitudinal trends of standing stocks, distributions and analysis of food vacuole contents. Aquat. Microbial Ecol., 24: 297-311.

Ramanathan, N.; Padmavathy, P.; Francis, T.; Athithian, S. and Selvaranjitham, N. (2005). Manual on polyculture of tiger shrimp and carps in freshwater,Tamil Nadu Veterinary and Animal Sciences University, Fisheries College and Research Institute, Thothukudi, vol. 1-161.

Utermohl (1958). In Vollenweider R.A. (1974). A manual of methods for measuring primary production in aquatic environments. IBP Handbook no. 12 London, Blackwell, p.8.

Vickerman K.(1992). Diversity and ecological significance of protozoa. Biodivers. Conserv., 1 (4): 334-341.

Weikert, H. (1982). The vertical distribution of zooplankton in relation to habitat zones in the area of the Atlantis II Deep Sea central Red Sea. Mar. Ecol. Progressive Series. B. Pp. 129-143.

Zakaria, H.Y. ( 2015). Article Review: Lessepsian migration of zooplankton through Suez Canal and its impact on ecological system. Egyp. J. Aqua. Res., 41(2): 129-144. 


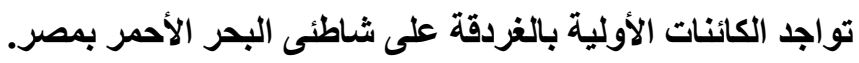

منصور جلال

قسم علم الحيو ان-كلية العلوم جامعة عين شمس

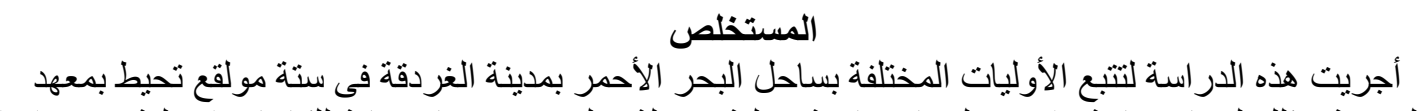

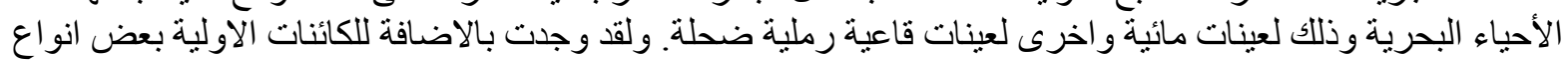

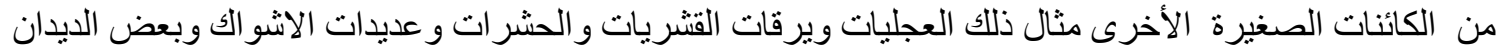

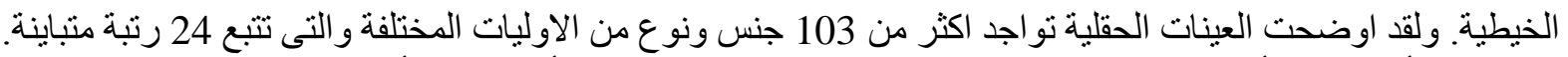

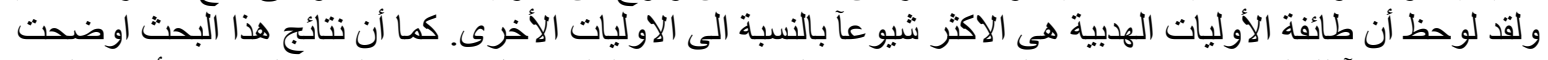

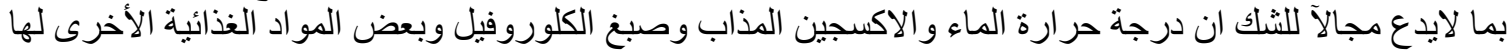

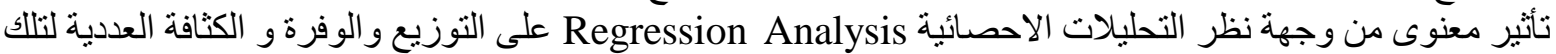

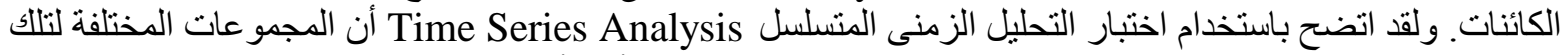

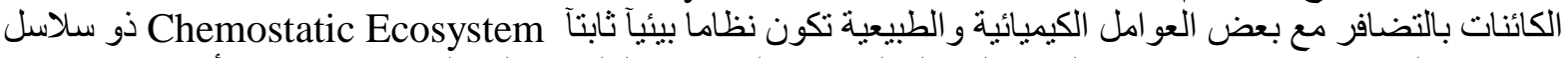
غذائية مختلفة ومتزنة مما يؤدى فى النهاية الى التخلص من الكثير من الملوثات المختلفة عضوية كانت أم غير عضوية. 